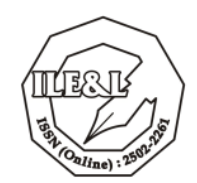

Journal Indonesian Language Education and Literature Vol. 3, No. 1, Desember 2017

http://www.syekhnurjati.ac.id/jurnal/index.php/jeill/

\title{
PENINGKATAN KESADARAN MEMBUANG SAMPAH PADA TEMPATNYA MELALUI PENDEKATAN HYPNOTEACHING
}

\author{
Mohamad Ali Zahidin, Hikmah Uswatun Ummi" Nina Nurfiana, \\ dan Emah Khuzaemah \\ IAIN Syekh Nurjati Cirebon, Indonesia \\ hikmahuu@gmail.com
}

\begin{abstract}
Abstrak
Kebiasaan membuang sampah sembarangan ini jika dibiarkan akan menimbulkan masalah kesehatan dan lingkungan yang berbahaya bagi masyarakat Indonesia. Perlu ada solusi untuk mengatasi masalah ini. Agar bahaya sampah tidak berhenti pada buku teks pelajaran, guru sebagai pengelola pembelajaran harus mampu mengemas pembelajaran agar anak-anak sebagai generasi masa depan bangsa Indonesia mempunyai kompetensi yang sesuai dengan apa yang diharapkan. Penelitian ini dilakukan di kelas 3 SDN 1 Serang. Penggunaan teknik Hypnoteaching dalam mendongeng memengarungi tingkat kesadaran pada siswa. Penyampaian dongeng dengan menggunakan media yang bervariasi juga dapat memengaruhi daya tangkap siswa dalam memahami dongeng tersebut. Hasil pengamatan menunjukkan bahwa (1) pada prasiklus dari 26 siswa hanya 19,23\% siswa yang membuang sampah pada tempatnya. Artinya hanya 5 siswa yang membuang sampah dengan benar; (2) pada siklus pertama 61,54\% siswa sudah membuang sampah pada tempat sampah, artinya 16 siswa membuang sampah pada tempatnya; (3) pada siklus kedua 92,31\% siswa sudah membuang sampah pada tempatnya, sedangkan 7,69\% atau 2 siswa yang masih membuang sampah sembarangan. Dengan demikian dapat disimpulkan bahwa melalui pendekatan hypnoteaching dengan metode mendongeng mampu meningkatan kesadaran siswa dalam membuang sampah pada tempatnya sebesar.
\end{abstract}

Kata kunci: dongeng, foklor, hypnoteaching, kepedulian sosial, lingkungan

\begin{abstract}
This habit of littering if left unchecked will cause health and environmental problems that are harmful to the people of Indonesia. There needs to be a solution to solve this problem. In order not to stop the garbage hazard on textbooks, teachers as learning managers should be able to package the learning so that children as future generations of the Indonesian nation have competencies that match what is expected. This research was conducted in grade 3 SDN 1 Serang. The use of Hypnoteaching techniques in storytelling underlines the level of awareness among students. Submission of fairy tales by using varied media can also affect the ability of students to understand the fairy tale. The results showed that (1) in precycle of 26 students only $19.23 \%$ of students dumped the garbage in its place. This means that only 5 students throw garbage properly; (2) in the first cycle $61.54 \%$ of the students have already dumped the garbage in the trash, meaning that 16 students throw the garbage in its place; (3) in the second cycle $92,31 \%$ of students already throw garbage in place, whereas $7,69 \%$ or 2 students still throw garbage carelessly. Thus it can be concluded that through hypnoteaching approach with storytelling method can increase the awareness of students in disposing of waste in its place of equal.
\end{abstract}




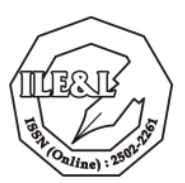

Journal Indonesian Language Education and Literature Vol. 3, No. 1, Desember 2017 http://www.syekhnurjati.ac.id/jurnal/index.php/jeill/

Keywords: the tale, folklore, hypnoteaching, social awareness, environment

\section{A. Pendahuluan}

Masalah sampah merupakan masalah rumit yang hampir tidak pernah terselesaikan dari masa ke masa pemerintahan di Indonesia. Pada kenyataanya, jumlah anggaran khusus yang digelontorkan pemerintah belum mampu mengentaskan masalah sampah yang sudah menjadi pekerjaan rumah dari masa pemerintahan sebelumnya. Hal ini dapat dilihat dari fakta bahwa Indonesia menempati urutan kedua di dunia terbanyak membuang sampah plastik di lautan (Tuwo, 2017). Cerminan tersebut dapat dipahami dengan mengamati perilaku masyarakat Indonesia yang menjadikan membuang sampah sembarangan menjadi sebuah kebiasaan. Seperti di wilayah Kupang, warga membuang sampah di tepi jalanan sudah menjadi hal lumrah bagi masyarakat Jalan Herman Johannes, Kupang, Nusa Tenggara Timur (Setiawan, 2017). Sementara itu, Sungai Ciliwung dipenuhi sampah plastik, styrofoam, dan sampah lainnya akibat kurangnya kesadaran warga untuk membuang sampah pada tempatnya (Fauzy, 2017).

Kabupaten Cirebon yang menjadi lokasi peneliti pun tidak luput dari masalah sampah tepatnya di Desa Tengah Tani, Sungai Cipager dipenuhi sampah kembali padahal sejak dua minggu yang lalu telah dibersihkan (Den, 2017). Berikut ini kasus mengenai sampah di Kabupaten Cirebon dan sekitarnya. (1) Warga memprotes Bupati Cirebon karena masalah sampah tak kunjung beres (2016). (2) Sampah menumpuk di Jalan Kesambi Kota Cirebon (Aryani, 2016). (3) Sampah di Sungai Kriyan, Lemahwungkuk Kota Cirebon, yang menyebabkan Erosi diangkut (Mik, 2017). (4) Empat buah Tempat Pembuangan Sampah (TPS) di Kota Cirebon tidak berfungsi karena warga membuang sampah sembarangan (Nirwan, 2017). (5) Tepi jalan di gerbang masuk Kota Cirebon di Kecamatan Sukapura dipenuhi sampah (Nirwan, 2017)

Kebiasaan membuang sampah sembarangan ini jika dibiarkan akan menimbulkan masalah kesehatan dan lingkungan yang berbahaya bagi masyarakat Indonesia. Perlu ada solusi untuk mengatasi masalah ini. Tindakan preventif dan kuratif perlu dilaksanakan. Saat ini, tindakan kuratif telah dilaksanakan di berbagai daerah. Contohnya, di kawasan Bundaran Hotel Indonesia pada saat Car Free Day penduduk yang membuang sampah sembarangan diberi hukuman berupa dipermalukan dengan diberikan kalung tulisan saya tidak akan membuang sampah sembarangan. Tetapi, 


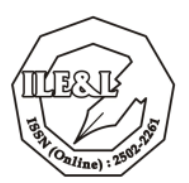

Journal Indonesian Language Education and Literature Vol. 3, No. 1, Desember 2017 http://www.syekhnurjati.ac.id/jurnal/index.php/jeill/

tindakan kuratif saja tidak cukup untuk mengatasi masalah. Oleh karena itu diperlukan tindakan preventif.

Pada kenyataannya, jiwa sosial dan kepedulian lingkungan pada jati diri siswa sebagai generasi bangsa Indonesia di masa mendatang hanya terdapat pada sebuah tekstual buku-buku pelajaran. Maka upaya untuk menginternalisasikan budaya malu membuang sampah sembarangan kepada peserta didik terutama anak-anak siswa sekolah dasar perlu segera diterapkan. Internalisasi budaya membuang sampah pada tempatnya kepada anak-anak menjadi jawaban atas tantangan bonus demografi Indonesia pada tahun 2020. Artinya, jika generasi muda tidak sadar dan tidak peduli lingkungan sekitar, jumlah sampah yang dihasilkan oleh seluruh penduduk Indonesia setiap tahunnya hanya akan menjadi sumber masalah bagi pembangunan Indonesia.

Agar bahaya sampah tidak berhenti pada buku teks pelajaran, guru sebagai pengelola pembelajaran harus mampu mengemas pembelajaran agar anak-anak sebagai peserta didik dan generasi masa depan bangsa Indonesia mempunyai kompetensi yang sesuai dengan apa yang diharapkan. Penggunaan metode yang menarik dalam pembelajaran merupakan salah satu cara agar siswa terangsang dan antusias dalam belajar. Metode mendongeng merupakan salah satu metode yang menarik untuk menginternalisasikan nilai-nilai moral tanpa harus membuat siswa merasa terpaksa. Metode mendongeng yang disajikan dengan menggunakan media visual (gambar) dan boneka membuat anak-anak tergugah untuk menyimak. Dongeng sebagai metode yang tepat untuk anak-anak dengan pendekatan hypnoteaching diharapkan mampu meningkatkan kesadaran membuang sampah pada tempatnya dan menghargai lingkungan sekitar. Lebih jauh lagi, dengan meningkatnya kesadaran membuang sampah, diharapkan metode mendongeng dengan pendekatan hypnoteaching mampu mengatasi problematika sampah di Indonesia.

Pengakuan wali kelas 3 SDN 1 Serang, Ibu Suryanti, S.Pd. tentang sulitnya meningkatkan kesadaran siswa-siswanya dalam membuang sampah sehingga membuat lingkungan sekolahnya kotor membuat peneliti tertarik melakukan penelitian di kelas 3 SDN 1 Serang. Sebelum melakukan penelitian, Peneliti melakukan proses prasiklus. Hasil prasiklus menunjukkan bahwa hanya 5 dari 26 siswa atau 19,23\% siswa kelas 3 SDN 1 Serang yang sudah membuang sampah pada tempatnya sehingga diperlukan penelitian lebih lanjut. 


\section{Journal Indonesian Language Education and Literature Vol. 3, No. 1, Desember 2017}

http://www.syekhnurjati.ac.id/jurnal/index.php/jeill/

\section{B. Metode Penelitian}

Penelitian ini menggunakan metode deskriptif analitis dengan teknik pengembangan deduktif. Metode deskriptif analitis merupakan studi untuk menemukan fakta dengan interpretasi tepat menggambarkan secara akurat beberapa fenomena kelompok atau fenomena individu, menentukan frekuensi terjadinya suatu keadaan untuk menimbulkan bias dan memaksimalkan reabilitasnya (Imawati, 2014:3). Teknik pengumpulan data yang dipergunakan dalam penelitian ini adalah observasi dan dokumentasi. Data diolah secara manual kemudian dideskripsikan. Analisisnya dikerjakan berdasarkan data yang dapat dikumpulkan setelah semuanya selesai. Berdasarkan dari penelitian di atas deskriptif analitis lebih lebih bersifat mencari sebabakibat terjadinya permasalahan dengan menggunakan metode $5 \mathrm{~W}+1 \mathrm{H}$, yaitu what (apa), who (siapa), where (dimana), when (kapan), why (mengapa), dan how (bagaimana).

Penelitian ini dilakukan di kelas 3 SDN 1 Serang Tahun Ajaran 2017-2018. Penelitian ini melibatkan seluruh siswa kelas 3 yang berjumlah 26 siswa dan peneliti sebanyak tiga orang. Adapun teknik pengumpulan data yang dipergunakan dalam penelitian ini adalah observasi dan dokumentasi. Penelitian ini mengacu pada Lewin (Sukmadinata, 2007:145) yang menggambarkan penelitian tindakan sebagai suatu proses siklikal spiral, yang meliputi: perencanaan, pelaksanaan, pengamatan, dan refleksi. Menurut Depdikbud, hubungan keempat komponen ini dipandang sebagai satu siklus (Zuliana, 2010:11). 


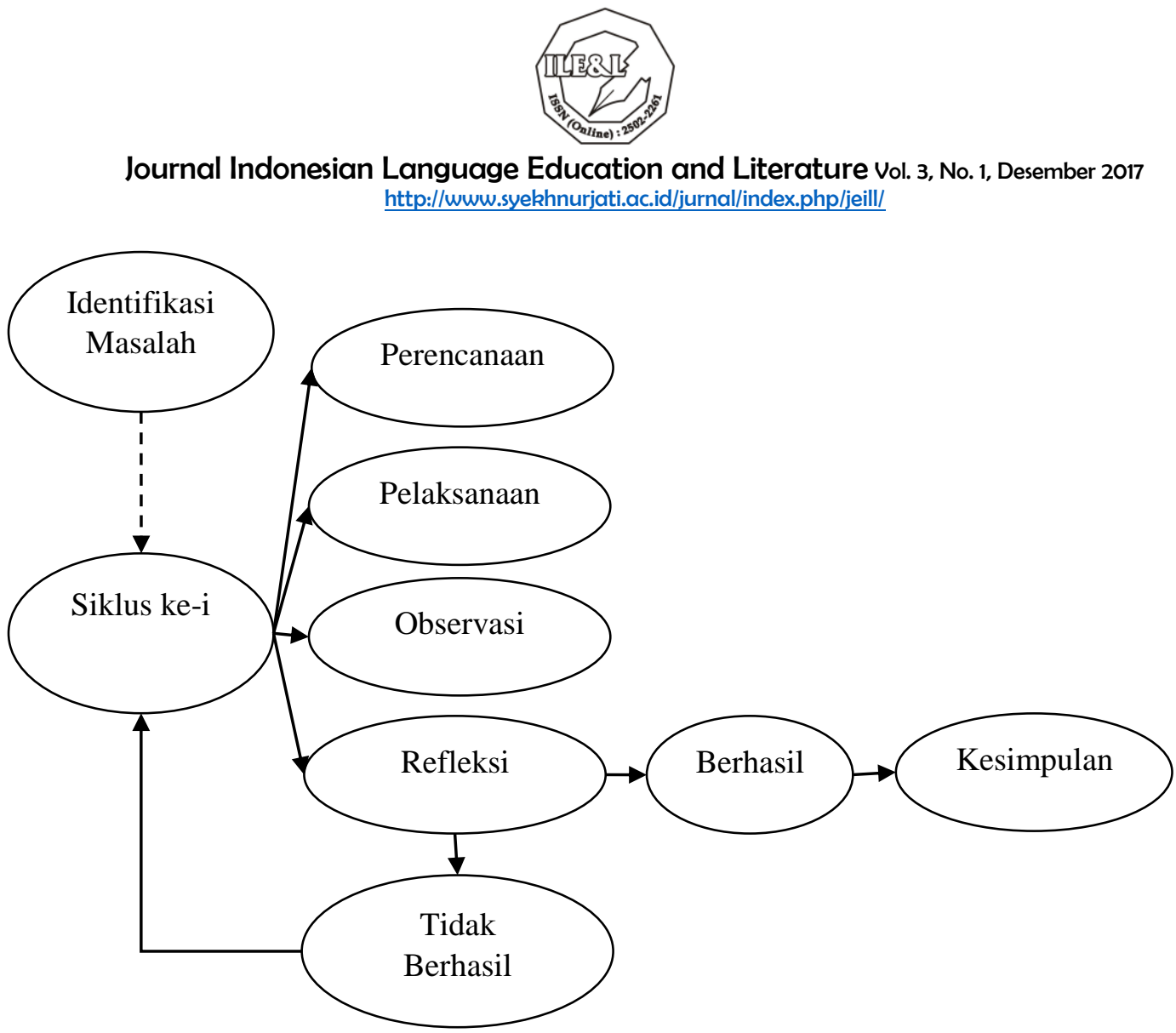

Gambar 1 Deskripsi Pelaksaan Siklus

\section{Hasil dan Pembahasan}

Penelitian ini merupakan Penelitian Tindakan Kelas yang dilakukan guru di dalam kelas yang bersifat praktis guna untuk mengetahui dan memperbaiki kekurangankekurangan pada saat proses pembelajaran dengan cara melakukan tindakan-tindakan. Siklus I. Adapun tahapan perencanaan Siklus I yang telah dilakukan peneliti yaitu menyusun skenario pembelajaran, membuat naskah dongeng, dan merencanakan media yang akan digunakan untuk mendongeng. Naskah dongeng yang disusun berjudul Sampah yang Berbicara. Dongeng ini menceritakan nasib sampah yang dibuang sembarangan dan nasib sampah lain yang didaur ulang. Peneliti menggunakan media gambar-gambar sampah sebagai tokoh dalam dongeng.

Penelitian pada siklus pertama dilakukan pada Rabu, 30 Agustus 2017. Jumlah siswa yang hadir saat itu 26 siswa. Artinya semua siswa kelas 3 SDN 1 Serang hadir. Adapun tahap pelaksanaan pada siklus I yaitu: 1) melaksanakan langkah-langkah pembelajaran sesuai dengan skenario pembelajaran; 2) mengenalkan bahwa sampah dapat didaur ulang dan bahwa sampah yang dibuang sembarangan akan berdampak buruk bagi lingkungan melalui metode mendongeng denngan pendekatan hypnoteaching. Pendekatan hypnoteaching yang digunakan melalui upaya menciptakan 


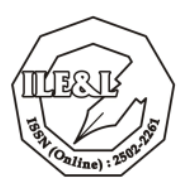

Journal Indonesian Language Education and Literature Vol. 3, No. 1, Desember 2017 http://www.syekhnurjati.ac.id/jurnal/index.php/jeill/

atmosfer kebahagiaan, mengkondisikan siswa pada zona alpha, sentuhan emosi, dan melakukan pengulangan terhadap lagu yang ada dalam sebuah dongeng; 3) meminta siswa untuk menjawab sebuah teka-teki mengenai kedaran akan membuang sampah; 4) sebelum pulang, Peneliti 1 memberikan makanan ringan sebagai bentuk apresiasi karena siswa telah mengikuti pembelajaran dengan baik. Kemudian siswa diminta untuk memakan makan ringan tersebut secara bersama-sama; dan 5) melakukan pengamatan terhadap aktivitas membuang sampah bekas makanan ringan tersebut.

Selama pelaksanaan siklus 1, dilakukan pengamatan terhadap respon siswa dalam mengikuti proses pembelajaran, bagaimana kemampuan siswa dalam mengutarakan amat yang terkandung dalam dongeng tersebut, serta aktivitas siswa dalam membuang sampah bekas makanan ringan setelah proses pembelajaran berlangsung. Setelah pelaksanaan pembelajaran siklus I ini dilakukan, peneliti menganalisis hasil pembelajaran yang telah dilaksanakan. Pada proses pembelajaran berlangsung sebagian siswa antusias ketika memperhatikan dongeng yang sedang diceritakan. Gambar sebagai media mendongeng pada siklus pertama menambah rasa penasaran dan menarik perhatian sebagian siswa. Ada hal menarik yang terjadi yaitu tindakan siswa laki-laki yang tanpa disuruh menyapu ruang kelas dan halaman depan kelasnya. Hasil penelitian yang dilakukan bahwa dari 26 siswa pada siklus 1 ini terdapat 61,54\% siswa atau 16 siswa yang membuang sampah pada tempatnya dan 38,46\% siswa atau 10 siswa kelas 3 di SDN 1 Serang masih membuang sampah sembarang.

Berdasarkan hasil pengamatan, tingkat kesadaran siswa dalam membuang sampah masih rendah. Lebih dari 1/3 siswa yakni 38,46\% siswa atau 10 siswa masih membuang sampah sembarangan. Penetili mencoba untuk membuat naskah yang lebih berkesan dengan menyantumkan sebuah nyanyian dalam dongeng untuk memudahkan siswa dalam menangkap dan mudah diingat, serta menggunakan media yang berbeda.

Siklus II. Adapun Tahapan perencanaan Siklus II yang telah dilakukan peneliti yaitu menyusun skenario pembelajaran, membuat naskah dongeng, merencanakan media yang akan digunakan untuk mendongeng, dan membuat permainan teka-teki silang. Naskah dongeng yang disusun berjudul Dua Tempat Sampah. Dongeng ini menceritakan kebingungan seorang tokoh saat hendak membuang sampah, sebab tempat sampah yang berada di tempat umum (taman) terdapat dua tempat sampah. Peneliti 


\section{Journal Indonesian Language Education and Literature Vol. 3, No. 1, Desember 2017 \\ http://www.syekhnurjati.ac.id/jurnal/index.php/jeill/}

menggunakan media boneka untuk memerankan tokoh dalam dongeng. Media boneka diharapkan lebih menarik perhatian siswa kelas 3 SDN 1 Serang.

Penelitian pada siklus pertama dilakukan pada Kamis, 31 Agustus 2017. Jumlah siswa yang hadir saat itu 26 siswa. Artinya semua siswa kelas 3 SDN 1 Serang hadir. Adapun tahap pelaksanaan pada siklus II yaitu: 1) melaksanakan langkah-langkah pembelajaran sesuai dengan skenario pembelajaran; 2) mengenalkan bahwa sampah tempat sampah yang baik yaitu terdapat dua tempat sampah yang berbeda yaitu organik dan anorganik sehingga siswa tidak salah memasukkan sampah yang sesuai dengan tempatnya melalui metode mendongeng dengan pendekatan hypnoteaching. Pendekatan hypnoteaching yang digunakan melalui upaya menciptakan atmosfer kebahagiaan, mengkondisikan siswa pada zona alpha, dan sentuhan emosi. Media boneka digunakan agar lebih menarik perhatian siswa; 3) meminta siswa untuk menjawab teka-teki silang secara berkelompok mengenai dongeng tersebut; 4) sebelum pulang, siswa diberi makanan ringan sebagai bentuk apresiasi karena siswa telah mengikuti pembelajaran dengan baik. Kemudian siswa diminta untuk memakan makan ringan tersebut secara bersama-sama dengan kelompok masing-masing; dan 5) melakukan pengamatan terhadap aktivitas membuang sampah bekas makanan ringan tersebut.

Selama pelaksanaan siklus II penelitian ini, Peneliti 3 melakukan pengamatan terhadap respon siswa dalam mengikuti proses pembelajaran, bagaimana kemampuan siswa dalam menjawab teka-teki silang mengenai dongeng, serta aktivitas siswa dalam membuang sampah bekas makanan ringan setelah proses pembelajaran berlangsung. Penggunaan boneka pada siklus ini menguatkan visualisasi dan menarik minat serta antusiasme siswa untuk mendengarkan dongeng secara keseluruhan. Pada setiap proses mendongeng, siswa diberikan sugesti positif berupa kalimat motivasi dan kalimat yang membangun internalisasi nilai-nilai kepedulian terhadap lingkungan dan sampahsampah yang berserakan. Karakter atau tokoh dongeng yang menghargai lingkungan membuat siswa menjadi menyadari bahaya akibat membuang sampah sembarangan.

Setelah pelaksanaan pembelajaran siklus II ini dilakukan, dilakukan analisis hasil pembelajaran yang telah dilaksanakan. Hasil penelitian yang dilakukan bahwa dari 92,31\% siswa atau 24 siswa sudah membuang sampah pada tempatnya, sedangkan 7,69\% atau 2 siswa yang masih membuang sampah sembarangan. Peningkatan yang secara signifikan tersebut terjadi karena siswa memasuki zona alpha pada saat proses 


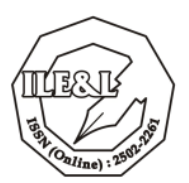

Journal Indonesian Language Education and Literature Vol. 3, No. 1, Desember 2017 http://www.syekhnurjati.ac.id/jurnal/index.php/jeill/

mendongeng berlangsung. Pada saat itu juga proses internalisasi karakter menghargai lingkungan sekitar dan kesadaran membuang sampah pada tempatnya secara alami masuk kedalam pikiran alam bawah sadar siswa melalui sugesti yang diberikan dalam dongeng sehingga sugesti tersebut melahirkan sebuah tindakan yang menjadi kebiasaan. Kebiasaan yang terbentuk itu pula yang melatar belakangi siswa malu ketika membuang samlah sembarangan dan sebaliknya siswa merasa bangga dengan membuang sampah pada tempatnya.

Berdasarkan hasil pengamatan, tingkat kesadaran siswa dalam membuang sampah meningkat 30,77\% pada saat peneliti menyampaikan dongeng dengan pengulangan lagu dan siswa pun langsung mengingatnya. Sehingga penelitian ini dianggap berhasil.

Kesadaran berarti keinsafan; keadaan mengerti: hal yang dirasakan atau dialami oleh seseorang, sikap, dan tingkah laku yang mendukung pengembangan lingkungan. Lingkungan adalah daerah (kawasan dan sebagainya) yang termasuk di dalamnya; bagian wilayah di kelurahan yang merupakan lingkungan kerja pelaksanaan pemerintahan desa; golongan; kalangan: semua yang mempengaruhi pertumbuhan manusia atau hewan. Kesadaran lingkungan sendiri merupakan pengertian mendalam pada orang seorang atau sekelompok orang yang terwujud dalam pemikiran. Kesadaran lingkungan merupakan usaha melibatkan setiap warga negara dalam menumbuh dan membina kesadaran utuk melestarikan lingkungan berdasarkan, tata nilai dari pada lingkungan itu sendiri dengan filsafat hidup secara dalam dengan alam lingkungannya. Kesadaran lingkungan adalah upaya untuk menumbuhkan kesadaran agar tidak hanya tahu tentang sampah, pencemaran, penghijauan, dan perlindungan satwa langka, tetapi lebih dari itu semua, membangkitkan kesadaran lingkungan masyarakat Indonesia khususnya pemuda masa kini agar mencintai tanah air. Seseorang yang sadar akan kebersihan lingkungan akan senantiasa lebih peduli baik dari segi pemikiran, sikap, dan tingkah laku yang mengarah pada lingkungan dan dirinya sendiri.

Hypnoteaching berasal dari dua disiplin ilmu yakni hipnotis yang memiliki pengertian proses mengkondisikan seseorang masuk kedalam alam bawah sadar dan teaching yang berarti pengajaran. Dengan kata lain, Hypnoteaching merupakan harmonisasi pengajaran yang melibatkan pikiran sadar dan pikiran alam bawah sadar. Kehidupan setiap orang dipengaruhi oleh dua macam pikiran yakni pikiran sadar (conscious mind) dan pikiran bawah sadar (subconscious mind). Melalui kedua macam 


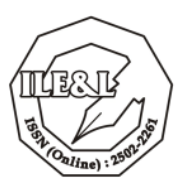

Journal Indonesian Language Education and Literature Vol. 3, No. 1, Desember 2017 http://www.syekhnurjati.ac.id/jurnal/index.php/jeill/

pikiran tersebut dihasilkan bentuk tindakan setiap orang. Secara umum kondisi hipnosis dapat digolongkan menjadi dua, yakni hipnosis sederhana (light hypnosis) dan hipnosis dalam (deep hypnosis).

Seorang guru yang mampu menembus critical area peserta didik dalam menyampaikan pelajaran akan memudahkan siswa untuk mengingat kembali pelajaran tersebut pada saat ujian. Hal tersebut terjadi karena pada saat pembelajaran siswa akan merekam isi materi menjadi ingatan jangka pendek. Keterampilan seorang guru yang mampu menembus critical area pada saat berlangsungnya materi disampaikan menjadikan ingatan jangka pendek menjadi ingatan jangka panjang. Untuk menembus critical area peserta didik seorang guru dapat melakukan lima upaya: 1) melakukan pengulangan, 2) menciptakan atmosfer kebahagiaan, 3) mengkondisikan siswa pada zona alfa, 4) pembawaan, dan 5) sentuhan emosi.

Dongeng merupakan cerita yang tidak benar-benar terjadi dan terkadang tidak masuk akal atau cerita fantasi yang aneh secara logika serta memiliki ketidakjelasan latar. Biasanya, sebagai keterangan waktu dongeng hanya mencantumkan frasa pada zaman dahulu. Begitupun dengan keterangan tempat, dongeng hanya memunculkan frasa di negeri antah berantah atau di suatu tempat nan jauh di sana atau di suatu tempat di pinggir hutan. Ketidakjelasan ini memberi kebebasan bagi anak untuk mengembangkan imajinasinya. Dongeng terbagi dua, yaitu dongeng klasik dan dongeng modern. Dongeng klasik muncul sejak zaman dahulu kemudian dilestarikan melalui tradisi lisan. Asal muasal dongeng klasik tidak diketahui. Setiap dongeng memiliki tujuan tertentu. Nilai-nilai moral dan nilai-nilai tradisional membuat dongeng klasik memiliki kekhasan tersendiri. Dongeng modern merupakan dongeng yang sengaja dibuat untuk dibaca orang lain. Dongeng modern dapat dikategorikan sebagai cerita fantasi. Berbeda dengan dongeng klasik yang anonim, pengarang dongeng umumnya mencantumkan namanya.

Dongeng tentang tokoh yang melakukan kebajikan dan memberikan pengaruh bagi dunia akan membuat anak yakin bahwa dirinya juga dapat melakukan kebajikan dan dapat memberikan pengaruh bagi dunia. Tanpa sadar, anak akan belajar pada tingkah laku tokoh yang dapat dijadikan panutan olehnya sehingga diperoleh nilai-nilai moral yang dipegang anak sampai dewasa. Dengan demikian dapat disimpulkan bahwa melalui pendekatan hypnoteaching dengan metode mendongeng, efektif untuk 


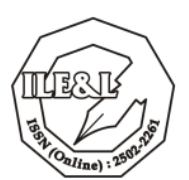

Journal Indonesian Language Education and Literature Vol. 3, No. 1, Desember 2017

http://www.syekhnurjati.ac.id/jurnal/index.php/jeill/

meningkatan kesadaran siswa dalam membuang sampah pada tempatnya. masih membuang sampah sembarang.

\section{Simpulan}

Hasil pengamatan menunjukkan (1) pada prasiklus dari 26 siswa hanya 19,23\% siswa yang membuang sampah pada tempatnya. Artinya hanya 5 siswa yang membuang sampah dengan benar; (2) pada siklus pertama 61,54\% siswa sudah membuang sampah pada tempat sampah, artinya 16 siswa membuang sampah pada tempatnya; (3) pada siklus kedua $92,31 \%$ siswa sudah membuang sampah pada tempatnya, sedangkan 7,69\% atau 2 siswa yang masih membuang sampah sembarangan. Dengan demikian dapat disimpulkan bahwa melalui pendekatan hypnoteaching dan metode mendongeng mampu meningkatan kesadaran siswa dalam membuang sampah pada tempatnya sebesar.

\section{Daftar Pustaka}

Aryani, Ani Nunung. (2016). "Hiiiyy... Kota Cirebon jadi Lautan Sampah" pada Pikiran Rakyat diakses 9 Desember 2016.

Fauzy, Naufal. (2017). Mirisnya Hulu Sungai Ciliwung, Masih Banyak Warga yang Buang Sampah Sembarangan (25 Juli 2017). Diakses di bogor.tribunnews.com

Imawati, S. (2014). Perkembangan Tambang Manga'an di Dusun Curah Wungkal Kecamatan Silo: Studi Konflik Pertambangan di Desa Pace Kabupaten Jember Tahun 2008-2009.

Nirwan, Fazri. (2017). "Duh, Warga Luar Kota Cirebon Disambut dengan Tumpukan Sampah" pada Radar Cirebon diakses 26 Juli 2017.

, Fazri. (2017). "Warga Masih Buang Sampah Sembarangan, 4 TPS Tak Berfungsi” pada Radar Cirebon diakses 26 Juli 2017.

Setiawan, Banny. (2017). Warga Masih Membuang Sampah Sembarangan (31 Agustus 2017). Diakses di kupang.uri.co.id

Sukmadinata, Nana Syaodih. (2007). Metode Penelitian Pendidikan. Bandung: Remaja Rosdakarya.

Tuwo, Andreas Gerry. (2017). "RI Penghasil Limbah Laut Terbesar Nomor 2 di Dunia" pada Liputan 6 diakses 2 April 2017. 
Journal Indonesian Language Education and Literature Vol. 3, No. 1, Desember 2017 http://www.syekhnurjati.ac.id/jurnal/index.php/jeill/

Zuliana, E. (2010). Meningkatkan Kemampuan Komunikasi Matematika Peserta Didik Kelas VIII B MTsN Kudus Melalui Model Cooperative Learning Tipe Jigsaw Berbantuan Kartu Masalah Kubus dan Balok. Refleksi Edukatika, 1(1), 17-33. 